\title{
The Bank Lending Process: Accounting Information Role in Constructing Realities or Illusions
}

\author{
Daniela Ruggeri ${ }^{1}$, Antonio Leotta ${ }^{1} \&$ Carmela Rizza $^{1}$ \\ ${ }^{1}$ Department of Economics and Business, University of Catania, Corso Italia, Italy \\ Correspondence: Daniela Ruggeri, Department of Economics and Business, University of Catania, Corso Italia, \\ Italy. E-mail: d.ruggeri@unict.it
}

Received: December 14, 2017

Accepted: January 2, $2018 \quad$ Online Published: January 15, 2018

doi:10.5539/ijbm.v13n2p53

URL: https://doi.org/10.5539/ijbm.v13n2p53

\begin{abstract}
In the last decades the Bank and finance literature have paid a growing attention to the bank lending process. Considering the different kinds of information, such as hard and soft information, involved in the risk evaluation, contributions to the bank lending literature have highlighted that small banks are better able to collect and act on soft information than large banks. In the bank lending process the risk can be assessed differently among actors, so the communication plays an important role in creating the firm rating evaluation. This paper aims to understand how the accounting information, as a language, could facilitate a successful functioning reality construction or an illusionary one. Drawing on the pragmatic constructivist perspective, which assumes the reality construction as the integration between facts, values, possibilities and communication, we try to understand how the actors integrate their different calculative cultures (calculative idealism and calculative pragmatism) in the bank lending process. In doing so, we carry out two case studies at two small banks operating in the South of Italy. The empirical evidences show how the presence of multiple calculative cultures has entailed disagreement, slowing down the lending process. The integration of the two calculative cultures has been showed underlining their complementarities. This paper contributes to highlight the useful role of the pragmatic constructivist approach to study the problem of the co-presence of different cultures within an organization, explaining how an integration can occur.
\end{abstract}

Keywords: bank lending, accounting information, calculative culture, pragmatic constructivism

\section{Introduction}

Bank and finance contributions have paid a growing attention to the risk management practices adopted by financial institutions such as banks (Mikes, 2011, 2009; Ball, Bushman \& Vasvari, 2008). In the last years, these organizations have faced off the Basel normative guidelines in managing the credit risk. In doing so, banks have revised their bank lending process adopting analytical models (i.e. firm rating) which supported the managers in the decisions related to grant or not grant the proposed loan. The lending decision has to take into account many attributes that cannot always be weighted in a normative way (Danos, Holt, \& Imhof, 1989; Crouhy, Galai, \& Mark, 2001). Thus, sharing (quantitative and qualitative) information represents a very important point in order to create a sufficient knowledge which could help to manage the risk in the bank-business relationships (Neef, 2005).

Considering the different kinds of information involved in the risk evaluation process, Petersen and Rajan (1994) have classified information in two categories: hard and soft. Hard information is produced by the analysis of financial documents and is always recorded in numbers; soft information is qualitative information, which can origin from internal or external sources, and it is often communicated in texts.

Contributions to the bank lending literature have highlighted that small banks are better able to collect and act on soft information than large banks. The latter are less willing to lend to informationally "difficult" credits such as in the case of small firms which are with pour financial records (Berger, Miller, Petersenc, Rajand, \& Steine, 2005) and are often so informationally opaque. The small-business lending relies on the production of soft information, which cannot be verifiably documented in a report that the loan officer can submit to his superiors. Under the so called the "lending relationship" (Petersenand \& Rajan, 1994, 1995; Berger \& Udell, 1995; Cole, 1998; Elsas \& Krahnen, 1998; Harhoff \& Koerting 1998; Berger \& Udell, 2002; Berger et al., 2005), small banks 
acquire information over time through contact with the firm, its owner, and its local community on a variety of dimensions, and use this information in their decisions about the availability and terms of credit to the firm.

In the bank lending process the risk can be assessed differently among actors, so the communication plays an important role in creating the firm rating evaluation. Given that, we wonder how the accounting information, as a language, could facilitate a successful functioning reality construction or an illusionary one.

Drawing on the pragmatic constructivist perspective, which assumes the reality construction as the integration between facts, values, possibilities and communication, we try to understand how the actors integrate their different calculative cultures in the bank lending process. Such cultures include the values that guide the bank actors in formulating the rating evaluation. Contributions in management accounting, analyzing the risk management practices, have identified two main calculative cultures which guide the risk managers in their decision processes (Mikes, 2009): calculative idealism and calculative pragmatism. The first is followed by risk managers who believe that the risk measures are capable of representing the economic reality observed. The second is followed by risk managers who trust lesser on numbers and try to integrate the quantitative information with qualitative information coming from their judgement based on their experience or on external sources.

In the bank lending process, the risk that the calculative cultures can be illusionary may arise. This is due to the dual nature of the risk management practices: "the assessment of probabilities and the degree to which such assessments can be represented objectively/technically by analysis (pragmatism)... and appraisals which reflect only the (subjective) conventions of risk assessors (constructivism)" (Lueg and Knapik, 2016, p.72). Adopting the pragmatic-constructivist approach, the actors' values and possibilities arising in the risk evaluation can create a fact-based reality.

The arguments developed in the theoretical part of the paper are used to explain the evidence drawn from two cases at two small banks operating in the South of Italy.

The main contribution of this paper is to highlight the useful role of the pragmatic constructivist approach to study the problem of the co-presence of different cultures within an organization, explaining how an integration can occur. Another contribution is directed to the risk management and to the management accounting literatures and is related to the role of different contents of accounting information in evaluating financial risk.

\section{Literature Review and Theoretical Framework}

\subsection{Literature Review on the Bank Lending Process}

In recent years, bank and finance literature has paid an increased attention to risk management at banks (Ball et al, 2008). Risk management can be viewed as a way of making the future manageable in a very specific way (Knights and Vurdubakis, 1993). To manage risk means to take responsibility for one's affairs by developing the means to avoid and repair its effects, and also to have available a set of tools or technologies that allow one to intervene in the name of risk.

In the last decades, risk management has drawn attention from several contributions, which have codified risk practices under the term enterprise risk management (ERM). Many banks have adopted the mission and principles of ERM (PricewaterhouseCoopers, 2005, 2007; Deloitte, 2007). In particular, exposing to multiple risks, banks have adopted sophisticated credit risk management systems that can account for borrower risk (e.g. rating), and, perhaps more important, the risk-reducing benefits of diversification across borrowers in a large portfolio.

Risk management at banks has often been described as a highly abstract, analytical activity that draws heavily on advances in statistics and financial economics (Bessis, 1998; Field, 2003; Marrison, 2002). The use of appropriate risk management tools help the risk manager to identify adequate capital requirements in proportion to the amount of risk taken, suggesting that banks should reserve more capital for higher risk-businesses and carry less capital for less risky ventures.

Among all bank activities, the decision making related to the request of financial loans by firms entails a relevant effort by bank's managers in collecting accounting/non accounting information in order to assess the risk related to provide the financial loan. Examining the bank lending process, Danos et al. (1989) have showed how the loan officers can use various types of accounting information in banks' credit-granting decision process: at the first stage the bank examines publicly available data on potential borrower in order to make a preliminary judgment on the quality of the proposed loan. So, the loan officers try to gather background information on firm's history and financial report information. The financial data can provide important signals to bank regarding firm's activities. The second stage "involves a personal "sizing up" of the borrower's business prospects and managerial skills" (Danos et al., 1989, p. 237). The loan officer tries to gather information from the client as to 
the purpose of the loan, their future operating plans and their financial plans for the repayment of the loan. At the final stage of the bank lending process, the bank produces a firm rating based on the historical and forward-looking accounting data. This phase culminates in a decision to grant or not grant the proposed loan. An individual or a group, depending on the authorized lending limit and other bank policies (in accordance to Basel II and III), makes the decision. The bank lending process ends with a firm rating report that synthesizes both quantitative and qualitative evaluations.

Crouhy et al. (2001) argued that the lending decision is based on many different attributes that cannot always be weighted in a normative way using a formal model. The loan officers must ascertain the financial health of the firm, and determine if earnings and cash flows are sufficient to cover the debt. In doing so, credit decisions are primarily based on credit scoring techniques, and secondly relied on the judgment of the ratings evaluators. The credit scoring techniques provide hard information which is almost always recorded as numbers. The latter derived by the analysis of financial statements, stock returns, and quantity output numbers. Contributions on the lending relationship literature have highlighted both the difficulties related to collect relevant information, which could be neither initially available in hard number nor are they easily or accurately reducible to a numerical score (Petersen and Rajan, 1994); and the importance to take into account the managers' judgment, based on their experience, and external qualitative information on the firm under-evaluation. This kind of information can be labelled as "soft" which is often communicated in text. It includes opinions, ideas, rumours, economic projections, statement of firm's future plans, and market commentary.

Thus, in the bank leading process sharing information is very important in order to create a sufficient knowledge which could help to improve the risk management practices (Neef, 2005). A crucial point is to understand how the information can support the decision making process of the bank's actors who are in charge of rating the riskiness of the firm requiring financial loans. Management accounting studies have heavily criticized the calculative rational approach drawn on a rational economic man with objective knowledge about actual performance and alternative courses of action and their future consequences (March, 1978). In the banks, such as in other organizations, the information about the consequences of lending practices is limited and uncertain due to the possible information asymmetry between the lender and the borrower. So, the production of evaluable information involves the co-authorship of multiple bank actors' perceptions of what may be factually possible and valuable in the future.

\subsection{The role of Accounting Information in Bank Lending Process: A Theoretical Framework}

Neef (2005) argued that "the key to a proactive risk management process lies in the company's ability to mobilize the knowledge and expertise of its employees so that organizational leaders can ensure that they get accurate and timely information" (Neef, 2005, p.114). But, how is the information in the bank lending process accurate and timely? "Data in itself reflects states of affairs in the world, but the relevant question is if and in what way specific states of affairs and data are relevant and essential in constructing a successful intended reality” (Nørreklit et al., 2017,p. 7).

A positivist approach might overlook human information processing in the bank lending analysis and assessment. Differently, Klinke and Renn, (2002) highlighted how a genuine constructivist approach could only focus on subjective assessment, which under-values the existence of facts in (the borrower) risk assessment (Klinke and Renn, 2002). The actors involved in the firm rating process need to mindfully reflect on quantitative data because these data alone could not represent one of the possible scenarios. Besides the numerical facts, actors also need to exercise judgment if the facts they encounter contain possibilities to manage risk (Nørreklit et al., 2010). When one of these possibilities becomes factual, the "firm rating" reality is constructed, and the decision making is accomplished. Accordingly, the firm rating practiced by banks in providing financial loans could be better understood using pragmatic constructivism (Nørreklit et al., 2017), which sees reality as a construction of four ontological dimensions: facts, possibilities, values and communication (Nørreklit, L., Nørreklit, H., \& Israelsen, 2006; Nørreklit H., Nørreklit, L., \& Mitchell, 2007; Nørreklit H., Nørreklit, L., \& Mitchell, 2010). Facts can be easily referenced, and be known from experience or systematic observation. "Facts are necessary as a basis of action... (but)... Facts alone are insufficient" (Nørreklit et al., 2010, p. 738), they do not constitute reality, "possibilities are also necessary, if one cannot recognise possibilities, then one cannot plan for the future" (Nørreklit et al., 2006, p. 46). Possibilities, grounded on facts, function only "if there is a reason to choose and prefer one possibility to the other i.e. if the actor has values and the values lie within the range of one's possibilities. Finally, the integration of facts, possibilities and values must be expressed in communication in order to enable action in a social setting." (Nørreklit et al., 2010, p. 738). The accounting information represents the language of the communication between actors, and it "is not a neutral medium that allows the world to present itself as it is; language shapes how reality becomes visible to social actors" (Kure, Norreklit , \& Raffnsoe-Moller, 2017). 
Thus, pragmatic constructivism provides some conceptual fundamentals for understanding and analyzing how actors construct personal and organized reality in a dynamic environment (Norreklit et al., 2017), clarifying why risk is assessed differently among actors, and how they can communicate to create a shared reality (Nørreklit, 2011). When the four dimensions are not integrated, the assessment deriving from bank lending process can be abstract and can lead to meaningless results (Nørreklit et al., 2006).

When the bank tries to evaluate the firm that asks for loan, it assigns a rating, drawn on financial quantitative data, according to the normative practices spread out by Basel accords (Basel II, and Basel III). Defining the firm capacity to reimburse the loan only in terms of quantitative criteria can guide the bank to observe the borrower very poorly, not considering subjective and complex aspects that can suggest the managers to formulate another kind of evaluation. In line with the lending literature, considering only the quantitative objectivity may entail an illusionary reality.

In a recent contribution Lueg and Knapik (2016), talking about the risk management from a pragmatic constructivist perspective, argued that the pragmatic-constructivist view allows for a dual risk management strategy in which values and possibilities create a fact-based reality. The risk management is in fact characterized by a dual nature: "the assessment of probabilities and the degree to which such assessments can be represented objectively/technically by analysis (pragmatism)(;)..Otherwise, appraisals reflect only the (subjective) conventions of risk assessors (constructivism)" (Lueg \& Knapik, 2016, p.72).

In line with that, Mikes (2009) argued that risk managers develop their personal philosophies about the manageability of risks that shape the composition of the risk management tools. Specifically, she identified two kinds of calculative cultures: calculative idealism and calculative pragmatism. The first is a calculative culture followed by risk managers who can be defined "quantitative enthusiasts". They manage risk by numbers, trusting that the risk measures are capable of representing the economic reality observed. "They put a high priority on building, maintaining and improving the 'robustness' and accuracy of their analytical models" (Mikes, 2009, p.22). So, the quantitative enthusiasts make their decisions on risk quantification rather than on judgmental risk assessments. The calculative pragmatism, differently, characterized the risk managers who trust lesser on numbers produced by risk analytics. Doing so, they can be defined as "quantitative sceptics" with regard to risk measures and trend indicators, which they seek to complement, and often overwrite by senior managerial discretion, experience and judgment.

In the bank setting: "intentional and unintentional usage of language to frame an issue mobilizes different groups of managers to invest in the issue. These framings, in turn, reflect different understandings of an issue and result in different patterns of attention allocation" (Dutton, 1997, p. 90). Given that, the bank lending process is advocated in both quantitative and qualitative information and its use depends on actors' appetite for, or resistance to, highly analytical (or highly judgemental) information (Mikes, 2009). It means that the technical analytical model used for formulating the firm rating in the credit-granting can be adopted in a calculative idealism culture, it might fail to resonate with one that takes a more incredulous approach to the benefits of quantitative modelling (calculative pragmatism culture).

These multiple calculative cultures can be defined in pragmatic constructivism terms as actors' topoi. The topoi are "the conceptual framework(s) used by an actor or group of actors in their reflections and method to control the reality construction (Norreklit et al., 2017, p.5). Different types of calculative topoi are involved in the establishment of construct causality (Leotta, Rizza, Ruggeri, 2017). We wonder how in the bank lending process the accounting information, as a language, facilitates a successful functioning reality construction or an illusionary one. It means to understand how loan managers develop and adjust their evaluation of borrower rating in order to construct functioning realities. In doing so, it could be relevant to consider how the different calculative cultures guide the managers in constructing the borrower evaluation, skipping the illusionary reality by the communication support of accounting language.

In what follows, two case studies on the small-bank lending process are presented, aiming to understand how calculative cultures, as topoi, can be integrated by the actors. In doing so, particular attention will be paid to how the accounting information, as a language, could facilitate a successful functioning reality construction or an illusionary one.

\section{Research Method and Banks Profiles}

In order to improve our understandings of the role played by accounting information in facilitating a successful functioning reality construction in the bank lending process, we carried out two case-studies at two local small-sized banks located in the South of Italy. The two banks are two local banks oriented to improve the relationship with the social actors that operate in the same local context. They were founded by local 
entrepreneurs whose aim was to support the growth of their territory by providing a financial support to the small firms in their businesses. The banks' mission was to offer financial services and managing the bank-business relationships in a direct and flexible way. In order to improve the local economy, the bank A aimed to invest a percentage of its profit in cultural and charity activities. The banks organizational structures were quite flexible. The bank A is articulated in only two branches and the client portfolio is composed only by small-medium businesses, most of them operating in the building sector. The bank B is articulated in few branches on the Sicily. Its client portfolio is composed of small-medium business.

The choice of the two local banks was due to the characteristics of their lending processes, which involved both hard and soft information in the decision to grant or not grant the financial loan required by the borrowers. The two banks were also selected for the co-presence of different calculative cultures which were involved in the construction of the final decision on the credit-granting. In the lending processes at the two banks the information was not collected by one individual or group and a decision made by another, such as in the large banks, differently in local banks all bank's actors involved in collecting the information were also involved in the final decision.

The cases followed a retrospective approach, intended to grasp subjects' perceptions of accounting information, as language, in facilitating the decision-making on loan required by the firm under evaluation (Jeacle, 2003; Jonsson, 1998; Scapens, 2004; Walsham, 2006). In our construction of these perceptions, we tried to direct the attention of the people in the field to the aspects they perceived as relevant in terms of fact and possibilities in the bank lending process. We also formed our own perception of final granting decision as reality construction, drawing on bank's archival data, considering accounting information included in report related to firm's financial data, financial ratios, and qualitative information related to the bank actors' judgments, market information, firm strategy information, confidential client information, and other internal documents being relevant for the facilitating role played by accounting information in the decision making on credit-granting.

Data were gathered over the period from June 2016 to August 2017. Our retrospective approach limited data sources to archive and field data coming from interviews with the main actors involved in the lending process at Bank A (sales manager, risk manager, credit manager, members of the Board of directors) and Bank B (sales manager, risk manager, financial analyst and members of the Board of directors) The semi-structured interviews, which lasted one hour and a half on average, were conducted during the years 2016 and 2017.

\section{The role of Accounting Information in the Bank Lending Process: Evidence from Two Cases Study}

\subsection{The Bank Lending Process}

When the bank lending process begins, the bank needs to evaluate the firm possibilities to timely repay the financial loan. In doing so, there are two risks that the loan manager has to take into account: the economic risk related to firm's insolvency and the financial risk when the firm fails in reimbursing the financial loans. In the last decades, normative changes have occurred in order to define a framework for banks' regulatory capital. In particular, Basel accords have identified some guidelines for the standardized approach to credit risk which is implemented by large banks. These technical and analytical tools support the bank in evaluating the credit risk in such a mechanic way. Information in a large bank is potentially collected by one individual or group and a decision made by another. Thus, the decisions must be made on information that is easy to transmit across physical or organizational distances. The information must also have a uniform interpretation which does not depend upon the context under which it was collected (Petersen \& Rajan, 1994).

For the small banks which operate in a small context where the bank-business relationships are very important, the bank lending process can assume different characteristics. The use of statistical model for assigning a rating to the firm is associated to the evaluation of qualitative information. In particular, the bank lending process starts with the "loan preliminary investigation" which is articulated in four steps. The first step is related to the firm's request for the financial loan. In this phase, the firm shares general financial data in order to evaluate its possibility to reimburse the loan. In the second step, the loan manager and the other bank's actors, involved in the evaluation process, try to collect qualitative information related to the market in which the firm operates and to the firm's strategies. The third step is dedicated to the financial statement analysis and the cash flow analysis. The financial ratios play an important role in evaluating the firm's insolvency. In the fourth step, the loan manager draws up a report in which quantitative and qualitative information is synthetized. This report is an important communication tool for the bank's actors who, based on this report, make their decision to grant or not to grant the proposed loan. Thus, the use of both hard and soft information could improve the loan preliminary investigation due to the evaluation of information that the financial numbers are not able to provide. In general, a firm's access to credit is a function of how much information is available to the financial markets. Firms, which 
are more informationally transparent, have a higher probability of their loans being approved (Petersen \& Rajan, 2002). Thus, small firms are more reliant on banks which usually collect and use soft and hard information. After the loan preliminary investigation, the credit manager submits the report containing the rating assigned to firm as a synthesis of soft and hard information, previously collected, to the Board of directors and the General Director, who have to produce a formal approval or not approval of the loan. Later, if the loan is granted, the bank provides the money required to the borrower.

\subsection{The Case of Bank " $A$ "}

In April 2014 the president of National Craft Trades Confederation argued: "it is a terrible moment for the craft sector... the companies will face off an Autumn worse than the previous one ... the financial crisis are hindering the building sector and our entrepreneurs are in trouble related to the bank credit granting... the rates are increasing and the reimbursement times are longer than the past years!".

In the last years, the building sector had suffered a reduced credit-granting: in the 2007 the percentage of credit-granting allocated to the building sector had been 30\% decreasing up to $14 \%$ in the 2014 . The Regional Bank Lending Survey conducted by the Bank of Italy had underlined that "the banks keep maintaining a prudential behaviour in credit-granting to building firms". This financial context had declared the failure of some building firms.

About the financial crisis which damaged the building sector, a manager of bank A argued: "given the bad financial context, the large banks were very sceptical in granting the financial loans required by the firms operating in the building market".

In June 2016 the firm "Alfa" operating in the building sector required a financial loan to the Bank A. The first approach was with the bank sales manager who formalized the client request, starting the loan preliminary investigation. He collected all firm's financial statements and information about the building market. At this phase, the aim of the sales manager was to verify the compatibility between the client request and the bank credit policy, evaluating the feasibility of the financial loan. Then the sales manager, supported by the risk manager, run an IRB approach (Internal Rating Based) in order to obtain a more accurate rating compared to that derived from a Standardized approach (external rating assigned by international rating agencies such as Moody's, Standard \& Poors, etc.). The accounting information derived by the financial statements was the factual resource.

The sales manager and the risk manager believed that risk calculations reflected underlying economic realities and "worr(ied) constantly about the 'robust' and 'hard' nature of . . risk analysis" (Power, 2003; p. 14). The risk manager placed the emphasis on the robustness and accuracy of the rating models. The abstract subject of accounting information became confined to financial and quantifiable credit risk. This conceptual content was translated into numbers, so the criterion was selected in accordance to the ideal use of the concept itself. The accounting data was used by sales manager and risk manager for formulating ratios that gave important information about the firm's solvency and profitability. On the basis of the collected data they classified the firm with a risk score of 9 on 10. The rating model adopted by the bank A following the Basel II normative guidelines, quantified in a score the firm risk, linking the Bank-business relationship to a quantitative number.

This quantitative evaluation showed the possibility that the bank should have had to refuse the client request for the financial loan. Following the bank mission to support the local firms, the loan preliminary investigation was analyzed by the credit manager. He was conscious about the negative decision that the bank Director and the Board of directors should have made on the basis of the quantitative evaluation. That was the reason why the credit manager decided to collect more information on the firm's businesses in order to understand if the risk score assigned to the firm could be maintained or not. He was sceptic about to consider only the quantitative evaluation submitted by the risk manager, showing a divergent opinion on the information to use in the lending process with respect to the risk manager. Moreover, the rating submitted by the risk manager seemed to configure the factual possibility to refuse the credit granting, the risk of illusionary accounting information occurred.

Clarifying why risk was assessed differently among bank's actors, and how they could communicate through the accounting language to create a shared reality was a very important point in the reality construction. So, when the fact, value and possibilities are not integrated by communication, the assessment deriving from bank lending process can be abstract and can lead to meaningless results.

The credit manager collected qualitative information concerned the firm entrepreneurs' background. This information was very important because Alfa was a young firm and it was difficult to provide so much information on its background. The good news was that the firm entrepreneurs provided their capital to buy the 
local land and the machines for starting the building project. The credit manager also collected information about the partnerships between Alfa and a local estate agents. The later was considered very reliable by the market due to its co-participation to other projects similar to the Alfa's one. They have an informal agreement on the building selling: if the financial loan might be approved, Alfa constructed the buildings and the estate agents could sell them improving its visibility on the local economic area. This soft information offered such a guarantee on the future good result of the Alfa project. However, analyzing the local surrounding area where Alfa wanted to develop its building project, the credit manager surprisingly noted how the sales prices and the building values were not decreased by the financial crisis.

This qualitative information and the previous rating based on quantitative information were examined by the credit manager, who submitted another report where the risk score assigned to Alfa decreased from 9 to 4 . The quantification of the firm risk assumed a different content.

The content of accounting information proposed by the risk managers to construct functioning realities was adjusted by the credit manager who tried to negotiate with the other actors what the rating evaluation meant for the Bank A. Understanding the role of the accounting information (hard and soft) in the lending process, meant to discover its actual, pragmatic function. Even if the actors recognized the same abstract meaning to the credit rating, the evaluation criteria followed by the credit manager were quite different. The combination of quantitative data translated into financial ratios and qualitative information, changed the pragmatic use of the rating evaluation in the bank lending decision making. It showed a different scenario on the factual possibility to grant the loan: the borrower was evaluated capable to repay the loan and the borrower was also willing to pay because it was considered valuable to do it on the basis of its transparency in sharing soft information.

Analyzing the bank lending process, the bank's actors involved in such a process followed two different calculative cultures: the Board of directors, the sales manager and the risk manager were quantitative enthusiastic of the rating obtained using the statistical model, conforming to the Basel normative guidelines; the credit manager instead was sceptic versus quantitative data, collecting more qualitative and subjective information that could help the Bank to enrich the lending process.

The co-presence of these two calculative cultures shows how the actors involved in the bank lending process followed different values that can help to show a spectrum of possibilities. The accounting information contained in the initial rating where integrated with soft information. So, the rating content recognized by the actors changed.

The bank actors such as the credit manager, the sales manager, the general director and the members of the Board of directors who followed different calculative topoi tried to communicate through the accounting information shared. The quantitative information at the first step of the loan preliminary investigation guided the bank actors to consider the possibility of not providing the loan to Alfa due to the worst rating assigned to it. At the first phase of the loan preliminary investigation, the Board of directors was in disaccord in granting the loan. They were sceptical in using qualitative information in the lending process due to the need to make homogeneous the collecting information among all the potential firms which can required a credit granting to the Bank. From the perspective the credit manager, the focus on quantitative data would have led to the construction of an illusionary reality. The calculative pragmatic culture of the credit manager let the soft information reach relevance in the bank lending process. The accounting information, both quantitative and qualitative, let to construct a different rating which was the product not only of the statistical model but also the result of information that was relevant in the evaluation of a building company.

This risk was considered as acceptable by the general director and the Board of directors who made the final decision to grant the financial loan. Some months later, the facts confirmed the correctness of the bank decision granting: in the first semester Alfa stipulated a good percentage of arbitration agreement, the estate agents sold the fifth per cent of the buildings that were in construction, and Alfa was able to reimburse the loan timely.

\subsection{The Case of Bank " $B$ "}

This is a case study on the loan request from a selling firm of agricultural machineries to bank B. The selling firm is a family firm founded in the ninety's. During the years, the top management decided to increase the number of non-family employees who were specialized in providing post-sales services. The firm had reached an important market share in the Sicily market, providing agricultural machineries to almost $70 \%$ of the potential customers. The selling firm had also offered to its clients the post-sales services which had the effect to increase the firm's earnings. The clients' portfolio was composed by both small agricultural firms, which frequently required high-technological machineries, and private customers who use the small agricultural tools for household use (i.e.: irrigation tools). 
In the last years the firm's organizational structure changed, assigning an important role to an external consultant, who introduced some managerial accounting tools in order to support the decision making processes with more accurate information about the firm's internal activities and the potential investments.

In June 2016 the top management of the selling firm, supported by the external consultant, decided to increase the firm's market share through new investments. That was the reason why the selling firm made a formal meeting with the sales manager of the bank B in order to start a loan preliminary investigation. At the first step, the sales manager required the last three financial statements in order to understand which was the firm's financial status. Analysing the accounting data contained in the official documents, which represented the factual resources, the sales manager and the risk manager selected the financial ratios that were usually included in the rating evaluation report. The financial ratios played an important role for the sales manager and the risk manager due to their role in communicating how much reliable was the selling firm in guaranteeing the reimbursement of the loan. The main ratios used by the risk manager are summarised in table 1.

Table 1. Ratios used in the Bank "B"'s rating evaluation

\begin{tabular}{ll}
\hline Average of storage days & 98,7 \\
\hline Cash flow/debts & $8 \%$ \\
Financial charges/revenues & $7 \%$ \\
Leverage & $40 \%$ \\
Financial charge/debts & $2 \%$ \\
\hline
\end{tabular}

The average of storage days gave information about how long the agricultural machineries stayed in the storehouse. The firm's value ratio was very high but it could be justified by the peculiarities of the agricultural machineries which were not bought and substituted frequently by the potential customers. The percentage of the second ratio indicates that the firm financial entries were higher than the outflows, giving positive information on the firm's financial status. The third ratio showed how the earnings were absorbed by the financial charges. The $7 \%$ indicated that the firm was able to cover the financial charges with the actual revenues. The fourth ratio instead provided information on the relation between debts and assets. Comparing the firm's leverage to the average competitors' leverage, the $40 \%$ showed that the firm was less run into debt that the other firms operating in the same market. Finally, the last ratio confirms that the firm was not dependent on external financial loans. The risk manager also underlined that the earnings flow was stable. This accounting information assumed a particular role for the actors involved in the lending process: the quantitative information was an important communication means of the good firm's financial equilibrium. In particular, the role of financial ratios was clear and shared between bank's actors who recognized the importance for the bank lending to observe some specific economic and financial aspect of firm's activities. The criterion was approved by bank's actors: the bank's lending policy was defined in the last years following the Basel suggestions. Looking at its client portfolio and the financial market peculiarities, the bank created its scoring model, personalizing the ratios to use in the rating report. The bank's actors agreed on using a specific combination of ratios.

The sales manager and the risk manager also collected information related to the market trends. The market analysis showed how the investments on agricultural machineries increased of $3 \%$ in the last year. This phenomenon was accompanied to the market growth due to the institutional laws which promoted some incentives for the young entrepreneurs who wanted to invest in the agricultural market. The risk manager tried to analyze the competitive position of the selling firm and the evaluation was positive due to the firm's competitive advantage represented by sophisticate management control systems already adopted to support the firm's decision-making processes. In order to complete the rating report, the sales manager and the risk manager collected information about the past bank-firm's relationships. The bank database showed how the firm's credit deposit was always positive, assuming a value around 15.000,00 Euros. Important accounting information was provided by the Automated Interbank Risk Service on the firm's accounts opened at other banks and on the firm's reliability to reimburse the loan provided by other banks. The selling firm did not have got any problem in managing the other bank-firm relationships. It was interpreted such as a good signal.

Quantitative information collected by the sales manager and the risk manager was weighted applying a scoring model for the rating evaluation. Information was weighted on its impact on the firm's solvency. The scoring model adopted by the Bank B gave more importance to the financial information leaving a little room for the qualitative information. The rating assigned was "A", identifying a firm in financial and economic equilibrium, able to face off the reimbursement of the provided financial loan and at the same time sensible to the market 
changes.

The rating elaborated in the Loan preliminary investigation was driven by a calculative ideal culture. The risk manager and the sales manager were characterized by strong enthusiasm for risk quantification expressed in the rating. The financial information derived from the financial statements represented the factual resources derived from the observation of the past. The possibility to grant the loan was suggested by the good rating score obtained by the firm (rating A). Thus, the facts observed from the past and the future possibility to grant the loan were integrated with the prevailing ideal value of the actors involved in the bank lending process and guided the actors to a reality construction. But what is relevant here is to understand the role played by the accounting information, as a language, in constructing the reality. The bank's policy on credit risk played an important role in the production and the use of the accounting information and supported the integration between the calculative values and the possibility to grant the loan. This entailed the prevailing of a calculative ideal topos that guided the actors in the evaluation process.

The rating report was also examined by an internal financial analyst, who had the role to approve the rating provided by the sales manager and the risk manager before submitting the final rating report to the Board of directors who made the decision on the financial loan. He aimed to understand if the rating score assigned to the selling firm really represented the firm solvency risk.

In doing so, the analyst met the firm's entrepreneur in order to collect other information that could be relevant for the credit-granting decision. He focused his analysis on the first semester of 2016. Accounting data related to this first semester was not taken into account in the rating report drawn up by the risk manager and the sales manager. The analyst noted that the earning drastically decreased. During the meeting with the entrepreneur, the later argued: "the sales decrease was due to the loss of an important client... his orders represented $30 \%$ of our earnings... it wasn't our fault! ... unfortunately there was big fire at the client industrial plant and they had to interrupt their production processes".

The financial analyst was conscious about the relevance of this qualitative information which could change the rating score, having a negative influence on the bank granting decisions. The financial analyst at the beginning was quite sceptical to use only quantitative data derived from the three financial statements provided by the firm. He recognized the importance of the soft information, but following a quantitative enthusiasm, estimated the potential effects translating the occurred fact in accounting numbers. To estimate the decrease in sales, the analyst referred to the last year sales, so a decrease of $30 \%$ meant to change the value of revenues from $4,000,000$ to 2,800,000 Euros. The loss of the client also changed the estimation of the accounting data used for the ratios as reported in table 2 .

Table 2. Accounting values ante and post qualitative information

\begin{tabular}{lrr}
\hline & $\begin{array}{l}\text { Ante qualitative information } \\
\text { Accounting values derived from the } \\
\text { last year financial statement }\end{array}$ & $\begin{array}{l}\text { Post qualitative information } \\
\text { Estimation of accounting value for the } \\
\text { current year }\end{array}$ \\
\hline Assets & 35.000 .000 & 34.750 .000 \\
Debts & 14.000 .000 & 14.960 .000 \\
Cash flow & 1.120 .000 & 148.000 \\
Financial charges & 280.000 & 328.000 \\
\hline
\end{tabular}

The estimation of accounting data showed how the firm's entries decreased more than the outflows, the financial charges and the debts also increased. These accounting data were used to adjust the values of the financial ratios contained in the rating report. In particular, as indicated in table 3 , the average of storage days was increased due to the loss of the important client, the firm's financial entries and the revenues were drastically reduced.

In the figure 1 is showed the rating report which compares the quantitative data obtained only considering the hard information, with the quantitative data as a result of the soft information effect. 


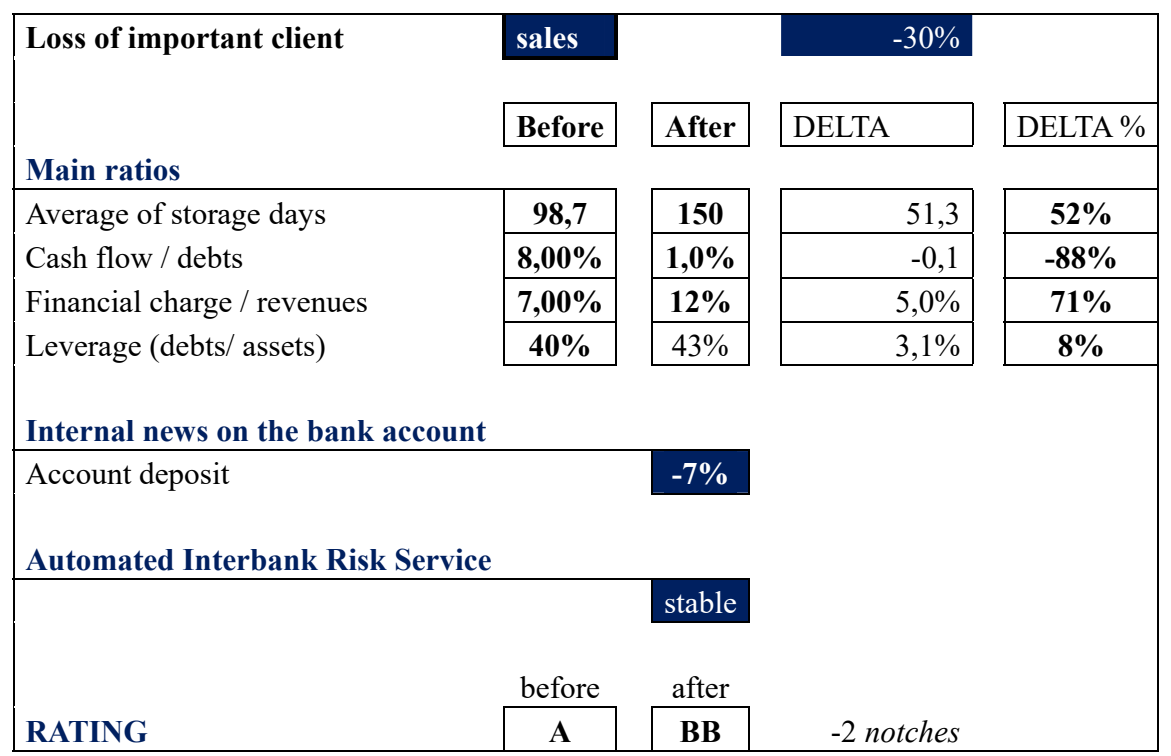

Figure 1. Rating report: the comparison before and after the use of soft information

The effect of the soft information was a decreasing in the rating score of two notches. The firm was not considered financial reliable due to the unstable economic and financial flows. The rating report elaborated by the sales manager and the risk manager showed through accounting numbers the possibility to grant the financial loan. The skeptical attitude of the analyst toward the historical accounting data led the actors not to recognizing the positive granting possibility as factual. In fact, this aspect was able to increase the bank's credit risk if the firm might be enable to reimburse the financial loan. The co-presence of multiple calculative topoi led the actors to complement their different values. The rating report showed two possible scenarios derived by different sets of hard and soft information. The new rating report was submitted to the Board of directors who agreed on the exemplary references offered by the report. The accounting information contained in the rating report integrated fact (historical accounting data), calculative values (calculative cultures) and possibilities (two rating scenarios). The resulting organizational topos came from an integration of multiple calculative topoi and let the decision of not granting the required loan become factual.

\section{Conclusions}

The paper has examined a very relevant issue in the bank and financial literature, namely the evaluation of creditworthiness by the bank. Management accounting studies have also dealt with the risk management, in its various forms, considering how accounting information is able to assess financial risk in both financial markets and bank-business relationships. The presence of two different approaches to financial risk evaluation have been related to the use of two different sets of accounting information, namely the so-called hard information, which contained financial information of the firm requiring the loan, and the so-called soft information, containing qualitative information about the business. The latter have been often intended to be complementary to the hard information and so it has been recommended to be used. Two calculative cultures have been conceptualized in describing the two alternative approaches in financial risk assessment, called calculative cultures. While the ideal calculative culture refers to the trust in the use of hard information, the pragmatic calculative culture describes the approach that is willing to use both hard and soft information in an integrative way.

Both the literature and the empirical evidences have highlighted the prevalence of ideal calculative culture in the lending process followed by large banks, while small banks are more willing to follow pragmatic calculative culture in their rating, but are often subject to the co-presence of both the cultures. It is the presence of multiple calculative cultures that may entail some problems in terms of coherence in the financial risk evaluation of the potential borrowers in their business relations.

The question the paper has addressed deals with how the different bank managers responsible of the various phases of the lending process can integrate their calculative cultures to share the same decision. The pragmatic constructivist approach was considered very useful in investigating this issue. It, in fact, recognizes an organization as a setting of multiple realities, such as different ways of observing the past facts, selected with specific sets of values, in order to derive future possibilities to be shared through communication and language. 
If the integration of facts, values, possibilities and communications is effective, then a unique and valid reality is constructed, which in social terms is named a valid topos. Applied to the issue of integrating the multiple calculative cultures within the lending process followed in a bank, the pragmatic constructivism views each calculative culture as the topos of an individual or a social group. The integration of a calculative, ideal topos with a calculative pragmatic topos is necessary for a bank to construct a unitary organizational calculative topos.

The two case studies analyzed have showed how the presence of multiple calculative topoi has entailed disagreement, slowing down the lending process. The integration of the two calculative cultures has been described highlighting the complementarities of the two topoi. The two cases have also emphasized two different aspects of the lending issue. While case A has focused more on the lending process followed within the bank, so highlighted the divergence in the calculative cultures of the various managers responsible of the different phases, the case $\mathrm{B}$ has showed the rating report, highlighting the impact of the integration in terms of complementarily of the information derived.

\section{References}

Ball R., Bushman R. M., \& Vasvari F. P. (2008). The Debt-Contracting Value of Accounting Information and Loan Syndicate Structure. Journal of Accounting Research, 46(2), 247-287. https://doi.org/10.1111/j.1475-679X.2008.00273.x

Berger A. N., Miller N. H., Petersenc M. A., Rajand R. G., \& Steine J. C. (2005). Does function follow organizational form? Evidence from the lending practices of large and small banks. Journal of Financial Economics, 76, 237-269. https://doi.org/10.3386/w8752

Berger, A. N., \& Udell, G.F. (1995). Relationship lending and lines of credit in small firm finance. Journal of Business, 68, 351-382. https://doi.org/10.1086/296668

Berger, A.N., \& Udell, G.F. (2002). Small business credit availability and relationship lending: the importance of bank organizational structure. Economic Journal, 112, F32-F53. https://doi.org/10.1111/1468-0297.00682

Bessis, J. (1998). Risk management in banking. New York, NY: John Wiley \& Sons.

Cole, R.A., 1998. The importance of relationships to the availability of credit. Journal of Banking and Finance 22, 959-977. https://doi.org/10.1016/S0378-4266(98)00007-7

Crouhy M., Galai D., \& Mark R. (2001). Prototype risk rating system. Journal of Banking \& Finance, 25, 47-95. https://doi.org/10.1016/S0378-4266(00)00117-5

Danos P., Holt D.L., \& Imhof E.A. (1989). The use of accounting information in bank lending decisions. Accounting Organizations and Society, 14(3), 235-246. https://doi.org/10.1016/0362-3682(89)90025-1

Deloitte, (2007). Global Risk Management Survey: Accelerating Risk Management Practices (5th ed.). Retrieved from http://www.deloitte.com/dtt/research/0,1015,cid\%253D151389,00.html

Dutton, J. E., Ashford, S. J., O’Neill, R. M., Hayes, E., Freeman, A. B., \& Wierba, E. E. (1997). Reading the wind: how middle managers assess the context for selling issues to top managers. Strategic Management Journal, $18(5)$ $407-425$. https://doi.org/10.1002/(SICI)1097-0266(199705)18:5<407::AID-SMJ881>3.0.CO;2-J

Elsas, R., \& Krahnen, J. (1998). Is relationship lending special? Evidence from credit-file data in Germany. Journal of Banking and Finance, 22, 1283-316. https://doi.org/10.1016/S0378-4266(98)00063-6

Field, P. (2003). Modern risk management - A history. London: Risk Books.

Harhoff, D., \& Koerting, T. (1998). Lending relationships in Germany: empirical results from survey data. Journal of Banking and Finance, 22, 1317-54. https://doi.org/10.1016/S0378-4266(98)000061-2

Klinke, A., \& Renn, O. (2002). A new approach to risk evaluation and management: Risk-based, precaution-based, and discourse-based strategies. Risk Analysis, 22(6), 1071-1094. https://doi.org/10.1111/1539-6924.00274

Knights, D., \& Vurdubakis, T. (1993). Calculations of risk: Towards an understanding of insurance as a moral and political technology. Accounting, Organizations and Society, 18(7/8), 729-764. https://doi.org/10.1016/0361-3682(93)90050-G

Kure N., Norreklit H., \& Raffnsoe-Moller M. (2017). Language games of management accounting- constructing illusion or realities? In Norreklit H. (Ed.), The Philosophy of management accounting. A pragmatic constructivism approach (pp. 211-224). Taylor \& Francis, 
Leotta, A., Rizza, C., \& Ruggeri, D. (2017). Management accounting and leadership construction in family firms. Qualitative Research in Accounting \& Management, 14(2), 189-207. https://doi.org/10.1108/QRAM-09-2015-0079

Lueg, R., \& Knapik, M. (2016). Risk management with management control systems: A pragmatic constructivist perspective. Corporate Ownership and Control Journal, 13(3), 72-81. https://doi.org/10.22495/cocv13i3p6

March J. G. (1978). Bounded Rationality, Ambiguity, and the Engineering of Choice. The Bell Journal of Economics, 9(2), 587-608. https://doi.org/10.2307/3003600

Marrison, C. (2002). The fundamentals of risk measurement. New York, NY: McGraw-Hill.

Mikes A. (2011). From counting risk to making risk count: Boundary-work in risk management. Accounting, Organizations and Society, 36, 226-245. https://doi.org/10.1016/j.aos.2011.03.002

Mikes, A. (2009). Risk management and calculative cultures. Management Accounting Research, 20(1), 18-40. https://doi.org/10.1016/j.mar.2008.10.005

Neef, D. (2005). Managing corporate risk through better knowledge management. Journal of the Learning Organization, 12, 112-124. https://doi.org/10.1108/09696470510583502

Norreklit, H. (2017). The Philosophy of management accounting. A pragmatic constructivism approach, Taylor \& Francis.

Nørreklit, H., Nørreklit, L., \& Mitchell, F. (2010). Towards a paradigmatic foundation for accounting practice. Accounting, Auditing \& Accountability Journal, $\quad$ 23(6), https://doi.org/10.1108/09513571011065844

Nørreklit, H., Nørreklit, L., \& Mitchell, F. (2007). Theoretical conditions for validity in accounting performance measurement. In Neely, A. (Ed.), Business Performance Measurement - Frameworks and Methodologies (pp. 179-217). Cambridge: Cambridge University Press.

Nørreklit, L. (2011a). Actors and reality: A conceptual framewok for creative governance. In M. Jakobsen, I.-L. Johanson \& H. Nørreklit (Eds.), An Actor's Approach to Management: Conceptual Framework and Company Practices (pp. 7-38). Copenhagen: DJOEF.

Nørreklit, L., Nørreklit, H., \& Israelsen, P. (2006), Validity of management control topoi - towards a constructivist pragmatism. Management Accounting Research, 17(1), 42-71. https://doi.org/10.1016/j.mar.2005.04.002

Petersen, M., \& Rajan, R. (1994). The benefits of firm-creditor relationships: evidence from small business data, Journal of Finance, 49, 3-47. https://doi.org/10.2307/2329133

Petersen, M. A., \& Rajan, R. G. (1995). The effect of credit market competition on lending relationships. Quarterly Journal of Economics, 110, 407-443. https://doi.org/10.3386/w4921

Power, M. K. (2003). The Invention of Operational Risk. London School of Economics and Political Science, ESCR Centre for the Analysis of Risk and Regulation, Discussion Paper no. 16, London.

PricewaterhouseCoopers. (2005). The Journal - Special Risk Management ed. Accessed on www.pwc.com on 25 September 2006.

Pricewaterhouse Coopers. (2007). Creating Value: Effective Risk Management in Financial Services on 15 April 2007.

\section{Copyrights}

Copyright for this article is retained by the author(s), with first publication rights granted to the journal.

This is an open-access article distributed under the terms and conditions of the Creative Commons Attribution license (http://creativecommons.org/licenses/by/4.0/). 